\title{
KESESUAIAN ANTARA PERSIAPAN MENGAJAR DENGAN PELAKSANAAN PEMBELAJARAN OLEH GURU IPA SMP NEGERI SE KECAMATAN LENGAYANG KABUPATEN PESISIR SELATAN
}

\author{
Destaria Sudirman \\ Program Studi Pendidikan Biologi FKIP Universitas Riau Kepulauan \\ Koresponden: destaria_sudirman@gmail.com
}

\begin{abstract}
ABSTRAK
Guru merupakan salah satu unsur yang terlibat dalam proses pembelajaran. Berhasil atau tidaknya seorang guru dalam proses pembelajaran dipengaruhi oleh banyak faktor, salah satu diantaranya adalah bagaimana rencana persiapan mengajar yang telah dibuat atau dirancang oleh guru sebelum proses pembelajaran dan bagaimana dalam pelaksanaannya. Penelitian ini bertujuan untuk melihat apakah ada kesesuaian antara persiapan mengajar dengan pelaksanaan pembelajaran oleh guru IPA SMP Negeri se Kecamatan Lengayang Kabupaten Pesisir Selatan. Jenis penelitian ini adalah penelitian deskriptif. Populasi penelitian ini adalah seluruh guru IPA SMP negeri se Kecamatan Lengayang yang aktif mengajar pada semester satu tahun ajaran 2009/2010 yang tersebar pada 5 sekolah. Sampel dalam penelitian ini diambil dengan teknik saturation sampling. Jumlah sampel dalam penelitian ini sebanyak 21 orang guru IPA. Variabel dalam penelitian ini adalah kesesuaian rencana pembelajaran dengan pelaksanaannya di dalam proses pembelajaran. Data dalam penelitian ini adalah data primer yang diambil langsung dari sumber data yaitu guru IPA SMP Negeri se kecamatan Lengayang yang dijadikan sampel. Hasil penelitian menunjukkan bahwa guru IPA dalam proses pembelajaran ada membuat persiapan mengajar tapi dalam pelaksanaannya ada yang sesuai sebanyak 47,14 dan yang tidak sesuai sebanyak 52,86\% dengan apa yang telah direncanakan sebelumnya. Besarnya jumlah ketidaksesuaian disebabkan kurangnya kualitas rencana pembelajaran guru dan minimnya pengetahuan guru tentang manfaat serta fungsi rencana pelaksanaan pembelajaran dalam proses pembelajaran di dalam kelas.
\end{abstract}

Kata Kunci: Persiapan Mengajar, Pelaksanaan Pembelajaran, Kesesaian

\section{PENDAHULUAN}

Pendidikan merupakan suatu kegiatan rekayasa untuk mengendalikan learning guna mencapai tujuan yang direncanakan secara efektif dan efisien. Dalam proses rekayasa ini peranan teaching sangat penting, karena merupakan kegiatan yang dilakukan oleh guru untuk mentrasfer pengetahuan, keterampilan dan nilai pada siswa sehingga apa yang ditransfer memiliki makna bagi diri sendiri dan masyarakat (Zamroni, 2001:60). Apabila seorang guru akan mengajar bahan pengajaran mengenai setiap materi kepada siswanya, guru yang baik akan berusaha sedapat mungkin agar pengajarannya berhasil. Salah satu faktor yang bisa membawa keberhasilan itu, ialah guru tersebut membuat persiapan mengajar.

Persiapan mengajar yang dibuat guru adalah dalam rangka melaksanakan sebagian dari rencana bulanan dan rencana tahunan yang didalamnya terkandung tujuan 
pembelajaran, pokok bahasan yang akan diajarkan, bahan pelajaran, metode mengajar, media pembelajaran, dan alat evaluasi yang akan diberikan. Dalam mata pelajaran IPA yang diharapkan siswa mendapatkan pengalaman secara langsung. Persiapan yang matang sangat diperlukan hal ini disebabkan dalam mata pelajaran IPA siswa dibantu untuk mengembangkan sejumlah keterampilan proses supaya mampu mengungkapkan rahasia, mengenal dan memahami alam sekitar yang berkaitan dengan makhluk hidup dan makhluk tak hidup. Apabila seorang guru akan mengajar suatu materi setiap pokok/satuan bahasan kepada siswanya, ia harus mengadakan persiapan terlabih dahulu.

Hal ini berguna agar proses belajar mengajar dapat berjalan dengan lancar, sehingga tujuan yang telah di tetapkan dapat tercapai. Dalam menyusun persiapan mengajar berupa silabus, satuan pengajaran, dan rencana pembelajaran, seorang guru harus berpedoman pada materi/kurikulum yang akan diajarkan. Selain itu, guru juga harus berpedoman pada siswa yang akan diajar karena setiap siswa memiliki pribadi yang berbeda dan situasi dilingkungan sekolah juga harus menjadi pedoman bagi seorang guru. Sejauh ini di SMP N se Kecamatan Lengayang Kabupaten Pesisir Selatan, guru-guru IPA ada yang membuat sendiri rencana pembelajarannya namun ada sebagian guru dalam membuat persiapan mengajar secara kolektif dalam kegiatan musyawarah guru mata pelajaran (MGMP), sehingga bahan ajar guru menjadi seragam dan terkesan asal untuk memenuhi ketentuan administrasi sekolah saja sedangkan kebutuhan disetiap sekolah tidak sama, baik dari segi siswa, guru maupun sarana dan prasarana pendukung. Penelitian ini bertujuan untuk melihat kesesuaian antara persiapan mengajar dengan pelaksanaan pembelajaran oleh guru IPA SMP N se Kecamatan Lengayang Kabupaten Pesisir Selatan.

\section{METODE PENELITIAN}

Penelitian ini menggunakan metode penelitian deskriptif. Data dikumpulkan dengan teknik pengamatan (observasi) langsung menggunakan lembar observasi proses pembelajaran di dalam kelas untuk melihat kesesuaian antara persiapan mengajar yang telah dibuat guru dengan pelaksanaan pembelajaran

\section{HASIL DAN PEMBAHASAN}

Data dalam penelitian ini diambil berdasarkan observasi langsung untuk melihat kesesuaian antara persiapan mengajar dengan pelaksanaan pembelajaran oleh guru yaitu 
berupa rencana pelaksanaan pembelajaran. Observasi dilakukan pada masing-masing sekolah hanya satu kali. Dari dua puluh satu orang sampel yang dilihat kesesuaian antara persiapan mengajar dengan pelaksanaan pembelajaran oleh guru tidak ada satu pun yang sesuai.

Tabel 1. Persentase guru IPA yang membuat dan yang tidak membuat rencana pelaksanaan pembelajaran

\begin{tabular}{lccc}
\hline No & Kategori & Jumlah & Persentasi \% \\
\hline 1. & Guru yang membuat rencana pembelajaran & 21 & 100 \\
2. & Guru yang tidak membuat rencana pembelajaran & 0 & 0 \\
\hline \multicolumn{2}{c}{ Total } & 21 & 100 \\
\hline & Hasil analisis data tentang kesesuaian antara & persiapan & mengajar dengan
\end{tabular}
pelaksanaan pembelajaran oleh guru IPA dapat dilihat pada tabel berikut.

Tabel 2. Persentase Kesesuaian Rencana Pelaksanaan Pembelajaran dengan Pelaksanaan pembelajaran di dalam kelas oleh Guru IPA se Kecamatan Lengayang Kabupaten Pesisir Selatan.

\begin{tabular}{clcc}
\hline No & \multicolumn{1}{c}{ Indikator } & \multicolumn{2}{c}{ Kategori (\%) } \\
\cline { 2 - 4 } & & 100 & Tidak Sesuai \\
\hline 1. & Identitas Sekolah & 100 & 0 \\
2. & SK dan KD & 100 & 0 \\
3. & Indikator & 100 & 0 \\
4. & Tujuan & 52,38 & 47,62 \\
5. & Metode/Strategi/Pendekatan & & \\
6. & Langkah-langkah Mengajar & & \\
& a. Pendahuluan & 14,29 & 85,71 \\
& - Apersepsi: Judul/Topik & 14,29 & 85,71 \\
& - Menjelaskan Tujuan & 76,19 & 23,81 \\
- Motivasi & 19,05 & 80,95 \\
- Waktu & & \\
b. Kegiatan Inti & 57,14 & 42,86 \\
- Langkah-langkah Pelaksanaan & 95,24 & 4,76 \\
- Uraian Materi yang Disampaikan & 4,76 & 95,24 \\
- Waktu & & \\
c. Kegiatan Penutup & 61,90 & 38,10 \\
- Menyimpulkan & 9,52 & 90,48 \\
- Evaluasi & 42,86 & 57,14 \\
- Tugas & 0 & 100 \\
- Waktu & 61,90 & 38,10 \\
Alat (Bahan/Media/Sumber) & &
\end{tabular}




\begin{tabular}{|c|c|c|c|}
\hline \multirow[t]{2}{*}{ No } & \multirow[t]{2}{*}{ Indikator } & \multicolumn{2}{|c|}{ Kategori (\%) } \\
\hline & & Sesuai & Tidak Sesuai \\
\hline \multirow[t]{6}{*}{8.} & Alat Evaluasi & & \\
\hline & - Bentuk/Jenis & 9,52 & 90,48 \\
\hline & - Cara Pelaksanaan & 9,52 & 90,48 \\
\hline & - Waktu & 9,52 & 90,48 \\
\hline & Total & 942,76 & 1057,24 \\
\hline & Rata-rata & $47,14 \%$ & $52,86 \%$ \\
\hline
\end{tabular}

Dalam hal ini kebanyakan guru IPA dalam pelaksanaan tidak sesuai dalam efisiensi penggunaan waktu, pemberian apersepsi pada siswa saat proses belajar mengajar dimulai, metode yang digunakan, dan pada saat proses belajar mengajar berakhir guru juga tidak mengadakan evaluasi, kurang pengelolaan kelas serta tidak disampaikannya tujuan pembelajaran pada hari itu kepada siswa. Padahal penyampaian tujuan sangatlah penting karena dengan adanya tujuan guru dan siswa dapat fokus terhadap apa yang diajarkan. Hal ini senada dengan yang dikatakan Zaini (2002:59), ada 4 dasar pemikiran yang berkaitan dengan mengapa harus merumuskan dan menyampaikan tujuan dalam proses pembelajaran yaitu: 1) untuk memfokuskan pengajaran terhadap apa yang seharusnya diajarkan dan untuk menghindari pemberian materi yang tidak relevan, 2) untuk memfokuskan terhadap apa yang harus dipelajari, 3) untuk menentukan metode yang lebih disukai atau sesuai untuk pengajaran.

Ketidaksesuaian rencana pembelajaran sebagian besar juga dipengaruhi oleh kurangnya fasilitas dari sekolah salah satu diantaranya buku paket. Buku paket tidak bisa dipinjamkan kepada siswa karena jumlah yang terbatas, sehingga siswa hanya bisa menggunakan buku paket waktu pembelajaran di dalam kelas. Hal ini mengharuskan guru untuk memberi waktu kepada siswa untuk meringkas materi pada waktu kegiatan inti, ini yang menghabiskan waktu pada proses pembelajaran.

Kualitas rencana pelaksanaan pembelajaran yang dibuat oleh guru juga kurang bagus tidak sesuai dengan format yang telah dikeluarkan oleh BSNP, walaupun sebenarnya tidak ada ditentukan bentuk atau format rencana pelaksanaan pembelajaran yang baku. Dalam sebuah rencana pelaksanan pembelajaran harus tercantum: 1) Identitas sekolah, 2) Alokasi waktu, 3) SK dan KD, 4) Indikator, 5) Tujuan pembelajaran, 6) Materi pembelajaran, 7) Metode pembelajaran, 8) Langkah-langkah kegiatan pembelajaran, 9) Sumber belajar, 10) Penilaian (Mulyasa, 2007:223). 
Sebagian besar rencana pelaksanaan pembelajaran yang dibuat guru SMP Negeri se Kecamatan Lengayang Kabupaten Pesisir Selatan tidak sesuai dengan format yang seharusnya. Hal ini terkesan guru asal buat rencana pembelajaran untuk memenuhi kebutuhan admnistrasi sekolah saja. Dalam pembelajaran guru juga tidak mempedomani dan memanfaatkan rencana pelaksanaan pembelajaran yang telah dibuat sebelumnya. Padahal rencana pelaksanaan pembelajaran merupakan sketsa/skenario yang akan dilakukan guru dalam proses pembelajaran sehingga apa yang ingin dicapai dapat terwujud.

Faktor lain yang menyebakan ketidaksesuaian rencana pelaksanaan pembelajaran dengan pelaksanaannya adalah guru yang mengajar tidak sesuai dengan keahliannya, maksudnya disini guru biologi mengajar fisika dan guru fisiak mengajar biologi. Jadi hal ini berpengaruh kepada penyusunan rencana pembelajaran yang dibuat dan pelaksanaan pembelajaran di dalam kelas.

\section{KESIMPULAN}

Semua guru IPA Negeri se Kecamatan Lengayang Kabupaten Pesisir Selatan telah atau ada membuat rencana pelaksanaan pembelajaran dalam proses pembelajaran. Guru yang membuat rencana pembelajaran 100\%. Dalam pelaksanaannya ada yang sesuai sebanyak $47,14 \%$ dan yang tidak sesuai sebanyak 52,86\% dengan persiapan yang telah dibuat sebelumnya. Besarnya jumlah ketidaksesuaian ini disebabkan kurangnya kualitas rencana pelaksanaan pembelajaran yang dibuat oleh guru dan minimnya pengetahuan guru tentang manfaat dan fungsi dari rencana pelaksanaan pembelajaran.

\section{REFERENSI}

Zamroni. 2001. Paradigma Pendidikan Masa Depan. Grafika. Yogyakarta.

Majid, Abdul. 2008. Perencanaan Pembelajaran Mengembangkan Standar Kompetensi Guru. PT. Remaja Rosdakarya. Bandung.

Mulyasa. 2007. KurikulumTingkat Satuan Pendidikan. PT Remaja Rosdakarya. Bandung. 